\title{
Carta del Presidente del CACl
}

Estimados amigos, cuando me propusieron escribir acerca de lo que el Colegio está haciendo mediante editoriales, dudé mucho de la conveniencia o no de que en una revista científica, como es la Revista Argentina de Cardioangiología Intervencionista, se incluyan editoriales no relacionados con temas médicos. Finalmente, me decidí a hacerlo porque es una nueva forma de llegar a ustedes acrecentando la comunicación y poner en vuestro conocimiento el rumbo que el Colegio va tomando.

El CACI es una institución joven y, como tal, aún tiene mucho por hacer. El más visionario de nosotros nunca se hubiera imaginado el Colegio que hoy tenemos: nuestra sede y las numerosas actividades que desarrollamos es una muestra de ello. Claramente, se destacan la actividad científica y educacional, lo gremial es una eterna deuda con el socio, pero el Colegio es mucho más.

Si bien teníamos claro los objetivos prioritarios y conocíamos el enorme desafío que se nos presentaba, la idealización con la que habíamos asumido pronto se esfumó ante la realidad de la gestión. El mismo día de asumir debimos afrontar el primer problema y apostar por una frase muy conocida, que dice: 区toda dificultad es una oportunidad ${ }^{\circ}$, y así lo tomamos. Esta inesperada situación exigía un compromiso para buscar soluciones a los reclamos gremiales planteados desde la ciudad de Córdoba y para ello, luego de un cuidadoso análisis de la situación, vimos que la solución podría ser reorganizar el mapa político del CACI eliminando las regiones y creando estructuras provinciales (llamadas consejos o delegaciones provinciales del CACI), con el fin de dar vida a un reclamo largamente postergado, cual es nuestra actividad gremial. Estas nuevas estructuras provinciales tendrían la capacidad de formular sus propios reglamentos de funcionamiento con fines sólo gremiales y con representatividad en el Colegio. Al crear estos nuevos organismos desde el CACI, les daríamos autonomía para actuar en defensa de la práctica ante los entes financiadores locales, respaldados siempre por el CACI, pero para ello debemos modificar nuestro estatuto, eliminar las regiones y crear los consejos o delegaciones provinciales y de Capital.

Por lo tanto, tenemos el desafío de estar a la altura de las circunstancias, hacer una correcta lectura de lo que el Colegio y nuestros socios necesitan y/o quieren, adaptarnos a los nuevos tiempos y hacer los cambios necesarios que nos impulsarán a sobrellevar con firmeza todas las dificultades que aparezcan. En este punto, es muy importante mantener viva la llama del sentido de pertenencia; debemos estar convencidos de que el Colegio somos TODOS nosotros, cada uno de ustedes señores socios, y que todos nuestros problemas, especialmente los mayores, podrán tener alguna solución sólo si trabajamos juntos, unidos y por un objetivo común.

Sin tiempo para la nostalgia, rápidamente comenzó el año, con una sucesión de actividades desafiantes, primero el Congreso SOLACI, luego nuestra sesión en el PCR, el Simposio GACI-CACI en la FAC, el ingreso de la Carrera UBA-CACI y los compromisos que aún quedan (TCT, SAC y nuestro congreso de Merlo \pm San Luis) desde lo científico.

Hemos pasado y estamos viviendo una serie de hechos que nos hicieron pensar en algunas medidas de fondo que creemos que debemos tomar para lograr los objetivos propuestos. 